\title{
シート状防風材を用いた木造断熱壁における通気層空隙 の確保に関する実験的研究 \\ PRESERVATION OF VENTILATED AIR SPACE IN THERMAL INSULATED WOODEN WALL WITH WIND BARRIER SHEET
}

\author{
鈴木大隆*，廣田誠一**，福島 明* \\ Hirotaka SUZUKI, Tomohito HIROTA and Akira FUKUSHIMA
}

\begin{abstract}
Ventilated air space separated from mineral wool by plastic thin wind barrier sheet will be narrower because of elongation of the sheet and spring of the mineral wool. This means that performance for vapor desorption and drainage of the air space will be insufficient.

Measurement and observation on experimental walls with various wind barrier shows that a little elongation of the sheet shut up the air space. Not only elongation of the sheet but also mineral wool type affect to the size of air space.
\end{abstract}

Keywords :wooden wall structure, insulation, air space method, wind barrier sheet, 木造外壁, 断熱, 通気層, シート状防風材

\section{1.はじめに}

地球環境の保全，居住空間の快適性向上の観点から， 全国的レベルで，戸建て中心とした往宅において断熱構 造化が急速に進行しつつある。戸建住宅の年間建設戸数 の $80 \%$ 以上を占める在来木造工法住宅において，外壁の 断熱化は, 殆どが柱・間柱間の空隙に䋐維系断熱材を充 填する方法によっている。実際，北海道や東北地方の一 部では, グラスウール等の㵶維系断熱材 $100 \mathrm{~mm}$ 壁内部 に全充填する断熱仕様がほぼ完全に定着している。また， 現在 $50 \mathrm{~mm}$ 断熱が定着している比較的温暧な地域でも， 暧冷房用エネルギーの低減等の理由から，今後徐々に $100 \mathrm{~mm}$ 断熱に移行する可能性が高い。

我が国の温暖多湿な気候風土に即し，在来木造工法は 構造木材の乾燥化のため, 躯体内部の換気通風を積極的 に図る納まりとなっている。これに対し，壁体内空陌に 緘維系断熱材を全充填した場合は, 躯体内通風が期待で きない構造となる。在来木造工法に限らず断熱化木造住 宅においては, 外壁構造木材の乾燥化 - 内部結露防止等
のために，断熱層内側に防湿層を，軸組外側に通気層を 設置することの必要性については, 筆者ら ${ }^{1)}$, 瀬戸ら ${ }^{2}$, 土屋ら ${ }^{3)}$ を初めとして既に多くの研究がなされ，その有 効性が報告されている。特に，通気層に関しては，土屋 $ら^{3)}$ は冬期の壁内防簬性や夏期の排熱効果の面から, 水 谷ら ${ }^{4)}$ はみかけの湿気貫流率測定による放湿効果の面か ら， $20 \mathrm{~mm}$ 程度以上の厚さが望まれると報告している。

これらの研究成果を基に，高耐久な断熱住宅の技術定 着に向けて本学会建築工事標準仕様書 JASS245) や公的 融資住宅の仕様書 ${ }^{6}$ ） 7)・基準解説書 ${ }^{8)}$ 等に防湿層・通気 層の設置の必要性や，通気層厚さは木造住宅で使われて いる一般流通汎用材の規格寸法を前提として，最低 $18 \mathrm{~mm}$ 程度以上確保することが記載されている。

通気層を設けた場合は，断熱材への雨水・冷気侵入防 止のため通気層と断熱層の境界面に防風層を設ける必要 がある。防風層には透湿防水性がある専用のシート状材 料と，シージングボード・構造用合板等のボード状材料 が一般に用いられているが，材工費の関係からシート状

\footnotetext{
* 北海道立寒地住宅都市研究所 工修

** 北海道立寒地住宅都市研究所
}

Hokkaido Prefectural Cold Region Housing and Urban Research Institute, M. Eng.

Hokkaido Prefectural Cold Region Housing and Urban Research Institute 
材料を使う場合が圧倒的に多い。シート状防風材は 0.1 $0.2 \mathrm{~mm}$ 厚程度とかなり薄く，伸び易い材質であるため， 䄉維系断熱材の復元厚さ・復元圧力によりシート材が通 気層側に脹らみ, 通気層空隙が減少する危険性があると 推測される。その結果, 壁体内部の水蒸気の放湿や, 乾 式外装材のジョイント部やシール部から侵入した雨水等 の排水が阻害されて木材が湿潤化し, 住宅の耐久性低下 につながる危険性も少なくない。本研究は，シート状防 風材を使用した場合の通気層空隙の確保に関して，実物 大モテルの施工実験から問題点を把握・整理し，工法的 提案を行うことを主な目的とするものである。

\section{2. 実験モテル概要}

北海道立寒地住宅都市研究所敷地内(札幌市内)に建つ 実験建物の南側外壁面 (幅 $9,100 \mathrm{~mm} \times$ 高さ 2,600 mm) で実験を行った。実験壁の平面・断面構成を図 1 に示す。 1 つのモテル寸法は，図 1 (a) に示す高さ $2,600 \mathrm{~mm}$ (土 台下端～軒桁上端） $\times$ 幅 $455 \mathrm{~mm}$ (柱芯々) からなる実 物大を想定した。壁内厚さは寒冷地に多い103 mm厚とし 往1), 木材乾燥による寸法変化の影響を極力少なくするた め, 軸組材・間柱等の下地材には全て乾燥木材（重量含 水率 $12 \%$ 程度）を使用した。その他の使用材料の選択 根拠・施工方法を, 軸組施工後の施工手順別に (1) (4) に示す。モテル施工工程は，実際の木造住宅と同じであ る。

\section{（1）シート状防風材}

現在市販・流通しているシート状防風材は 20 数種類に 上るが，その製法・材質から単一材料と複合材料の $2 つ$ に大別できる。このうち前者は不織布と有孔シートの 2 タイプ, 後者は基材・補強材の材質等の違いから 4 タイ プに分類される。

本論文では，単一材料のうち有孔（ピンホール）シー 卜は，強度・透水面から防風材として不適格という判断 注2）から，不織布に限定して市場流通品の中から 1 種を 選択した。また，複合材料については，上記 4 タイプ毎 に市場流通量が多いシート材 4 種を選択した。各シート 材は施工時に面内方向で緩み・伸びが生じないように間 柱・土台・軒桁外面四周でガンタッカー $150 \mathrm{~mm}$ 間隔で 留め付けた上で，通気胴縁材で挟み込み固定した。

\section{（2）通気層 - 外装材}

通気層は外壁下地材を兼ねた胴縁材 $(18 \mathrm{~mm} \times 45 \mathrm{~mm}$, 外装材継目部は $18 \mathrm{~mm} \times 105 \mathrm{~mm}$ ) で確保されることが多
く，通気層厚さは $18 \mathrm{~mm}$ 程度となるのが一般的である。 実際は使用胴縁材の乾燥度合いによって若干の幅がある。 ここでは，各モデルの通気層厚を正確に測定する必要が あるため, 乾燥材で厚さ $18 \mathrm{~mm}$ に揃えた胴縁材を使用し， 防風材を介して柱・間柱に釘で留め付けた。なお，外装 材は市販窝業系サイディング $12 \mathrm{~mm}$ 厚を使用し胴縁材を 下地として施工した。

\section{(3) 充填断熱材}

一般的に使用される外壁の断熱材は，ロール品，バッ

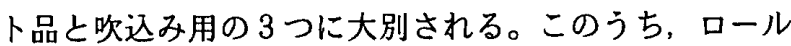
品は柱間寸法に合わせて現場切断するため施工精度が悪 くなる恐れがある。本実験では精度良く断熱施工するこ とが肝要なため，生産段階で間柱間寸法にプレカットさ れているバット品を使うこととし，現在北海道全域・東 北の一部で最も普及しているグラスウール（以下 GW） $16 \mathrm{~K}-100 \mathrm{~mm}$ と, 今後急速な普及が予想される高性能 GW 16K 䅅3) $-100 \mathrm{~mm}$ 及び GW24K-100 mm の 3 種を選択 し, 室内から壁内に充填施工した。吹込み用では, 外壁 用として寒冷地で一般的な接着材混入の GW (BIB工法)

表 1 実験モデル概要とモデル番号

（表中@印：空腺寸法測定 - 有効換気面糟測定，O印空隙寸法測定）

\begin{tabular}{|c|c|c|c|c|c|c|c|c|}
\hline \multicolumn{2}{|c|}{$\therefore 4+\cos$} & \multicolumn{2}{|c|}{ シート构監 } & \multicolumn{5}{|c|}{ 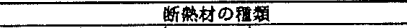 } \\
\hline$\dot{E}-r$ & 枋虽材 & \multirow[b]{2}{*}{ 惹 } & \multirow[b]{2}{*}{ 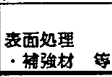 } & \multirow{2}{*}{$\begin{array}{c}\text { 一般品 } \\
\text { GW16K } \\
100 \mathrm{~mm} \\
\end{array}$} & \multirow{2}{*}{$\begin{array}{c}\text { 高性能 } \\
\text { WW16K } \\
100 \mathrm{~mm} \\
\end{array}$} & \multirow{2}{*}{$\begin{array}{c}\text { 一般品 } \\
\text { GW24K } \\
100 \mathrm{~mm}\end{array}$} & \multicolumn{2}{|c|}{ 吹迈子断鳘材 } \\
\hline & & & & & & & $\begin{array}{l}\text { GW } \\
\text { (BIB) }\end{array}$ & $\begin{array}{l}\text { ento- } \\
7 n+n^{\circ}-\end{array}$ \\
\hline 单一梦 & $\mathrm{A}$ & PE 系不餗布 & $12 \mathrm{~L}$ & (1) & (2) & (3) 0 & 00 & (9)@ \\
\hline \multirow{4}{*}{ 被合材 } & B & PE 系不建布 & P E系制右 & (5)() & (6) & & (1)O & (1) 0 \\
\hline & $\mathrm{C}$ & PE 系不赫布 & 多孔質ネット & (8)@ & (7) & & & \\
\hline & D & PS 系不維布 & 趞面コート & $(200$ & (13) 0 & & & \\
\hline & $\mathrm{E}$ & PS 系不耕布 & 多孔質ネット & (i) $\mathrm{O}$ & (190 & & & \\
\hline \multicolumn{2}{|c|}{ ボート状防图好 } & \multicolumn{2}{|c|}{ シーシンクボード12 mm } & & (4)(2) & & & \\
\hline
\end{tabular}

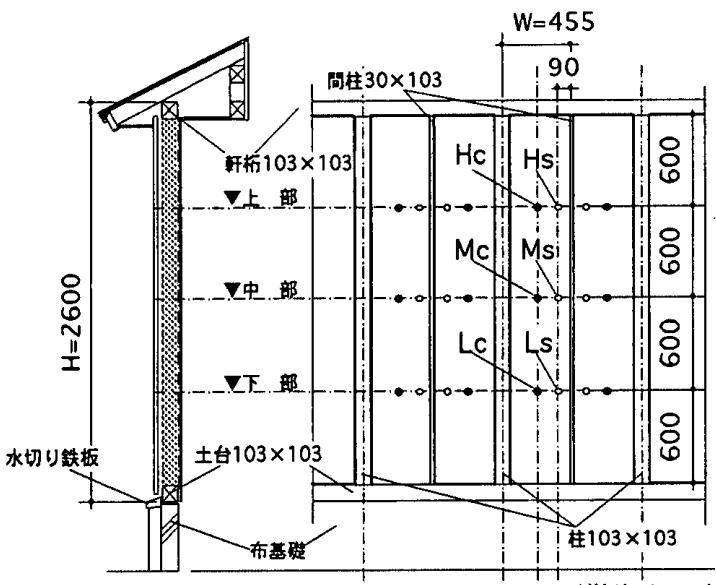

図 1 (a) 各測定点位置（単位は mm)

\begin{tabular}{|c|c|c|c|c|c|c|c|c|c|c|c|c|c|c|c|c|}
\hline (19) & (15) & (4) & (13) & (12) & (D) & (1) & (2) & (8) & (1) & (6) & (5) & (4) & (3) & (2) & (1) & \multirow{2}{*}{ 室内时 } \\
\hline 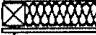 & 000000 & $\triangle 1000000$ & 10000 & $\overline{7}$ & & & & \multicolumn{8}{|c|}{ 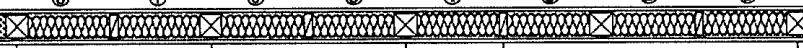 } & \\
\hline $\begin{array}{r}\text { 尙性能 } \\
\text { GW1 6K } \\
\text { シ }\end{array}$ & GW1 6K & GW1 6K & $\begin{array}{l}\text { 㣎性能 } \\
\text { GW1 6K }\end{array}$ & $\left|\begin{array}{r}\text { セルローX } \\
\text { ファイハ- }\end{array}\right|$ & BIB & BIB & $\begin{array}{l}\text { セルローズ } \\
\text { Pァイパー } \\
\text { 上A }\end{array}$ & GW16K & $\begin{array}{l}\text { 高性能 } \\
\text { GW16K } \\
. \\
\end{array}$ & $\begin{array}{r}\text { 高性能 } \\
\text { GW16K } \\
\text { シ- } \\
\end{array}$ & GW1 6K & $\begin{array}{l}\text { GW16K } \\
\dot{シ} \text { シシンタ } \\
\text { ホート }\end{array}$ & GW24K & $\begin{array}{l}\text { 高性能 } \\
\text { GW1 6K } \\
\text { シートA }\end{array}$ & GW16K & 屋外佂 \\
\hline
\end{tabular}

図 1 (b) モデル配置 
及びセルローズファイバー断熱の 2 方法を選択し, 各施 工要領書に従い施工した。

(4) 防湿材 - 内装材

断熱材内側の防湿材としてポリエチレンフィルム $0.2 \mathrm{~mm}$ 厚, 内装材として石膏ボード $9 \mathrm{~mm}$ 厚を施工した。 (5) 実験モデル種類

本論文で対象とした実験モデルは，シート状防風材 5 種と断熱材 5 種の組み合わせから計15タイプ, 比較検討 のためボード状防風材 (シージングボード $12 \mathrm{~mm}$ 厚) に よる1タイプ, 合計16タイプから構成される。モデル構 成を表 1 ，モデル配置を図 1 (b) に示す。

\section{3. 通気層空隌寸法の経時変化に関する検討}

\section{1 測定方法}

各モテルの通気層空隙は, シート状防風材の脹らみが 四周固定部分からの距離で異なると予想されるため, モ テル壁体上・中・下部 3 ヶ所において水平方向 (center 部：通気層胴緣材内法間の中央部分, $90 \mathrm{~mm}$ 部 : 胴縁材 内面より $90 \mathrm{~mm}$ 内側の部分) に2ヶ所, 計 6 点で測定し た。各測定点位置を図 1 (a) に示す。

このうち，モテル上中下部分の center 部 $\mathrm{Hc}, \mathrm{Mc}, \mathrm{Lc}$ は, シート材に断熱材の復元力が殆どかからない内装材施工 前之, 内装材施工により断熱材復元力がかかりシート材 が外側に脹らみ始める施工直後, 施工直後から寸法変化 が殆ど見られなくなった 301 日経過時まで 6 回, 合計 8 回の計測を行った。計測方法は，外装材に開けた测定孔 （直径 $30 \mathrm{~mm}$ ）から丸棒を差し込み, シート材から外装材 裏面までの空隙間隔を丸棒に印してノギスで計測し，空 隙寸法は計測值を四唅五入して $\mathrm{mm}$ 単位で表示した。

また，シート材は中央部を中心にほぼ対称形で脹らむ と予想されるため, $90 \mathrm{~mm}$ 部 Hs,Ms,Lsについてはモデ 毎に各 1 ヶ所で測定した。空隙寸法は, 内装材施工直後 と施工後26日経過時の合計 2 回の計測を行った。計測方 法は外装材施工前及び外装材を取り外した際に, 胴縁材 間に渡した角棒内側からシート材表面までの空隙間隔を 丸棒に印し上記と同様に計測・表示した。

\section{2 測定結果と考察}

（1） center 部 Hc,Mc,Lc の空隙寸法経時変化について 本実験では, center 部の空隙寸法はモデル上中下部で 計測しているが，経時変化については各点とも同じ傾向 を示している。その傾向は, シート材質より断熱材種別 で検討する方が良く説明できる。従って，ここではモデ ル中央部の経時変化を代表例として図示し，断熱材別に 経時変化について検討・考察する。

GW16K-100mm (一般品) を充填したモテルの通気層 空隙寸法の経時変化を図 2 に示す。内装材施工前は12 $14 \mathrm{~mm}$ 程度の空隙が確保されている。この断熱材は相当 な圧縮棝包で出荷されているため, JIS 規格では圧縮量を

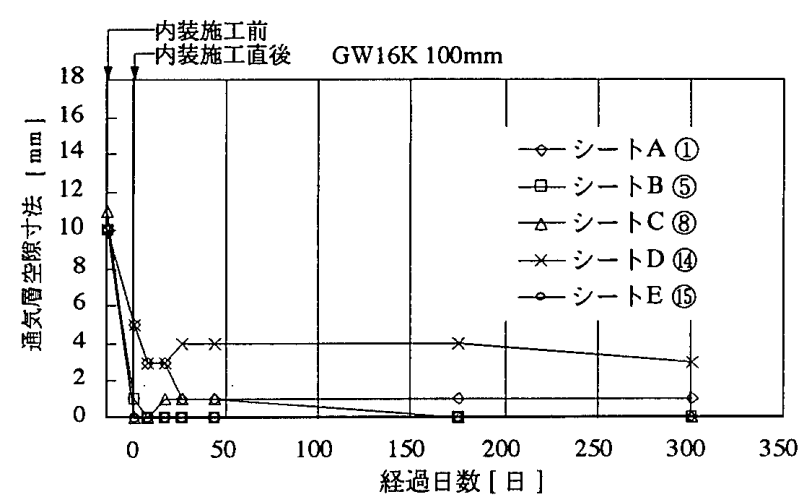

図 2 GW16K-100 mm（一般品）を充填したモテルの 通気層空隙寸法の経時変化

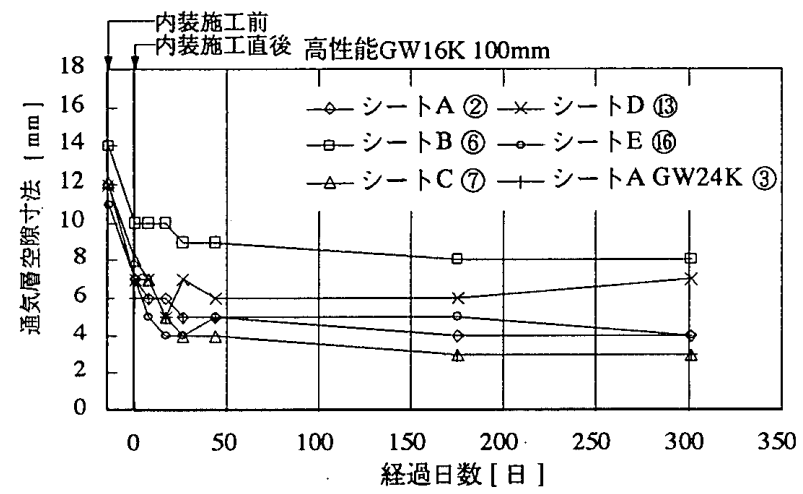

図3高性能 GW16K-100mm・GW24K-100mm を 充填したモデルの通気層空隙寸法の経時変化

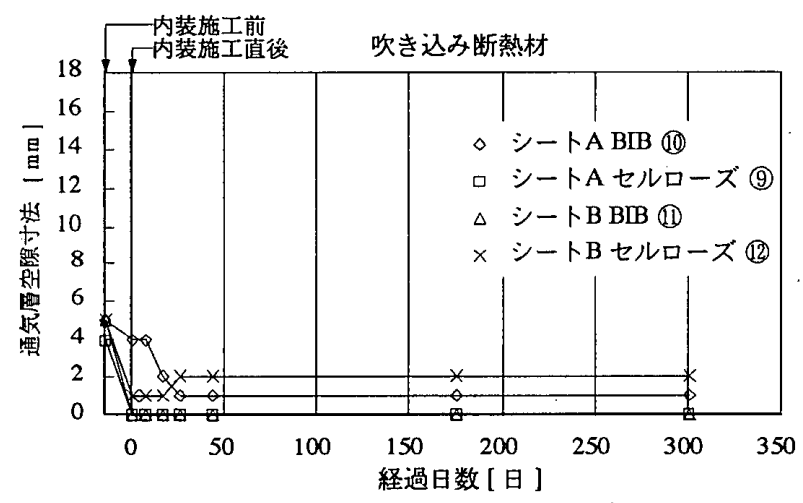

図 4 吹込み用断熱材を用いたモデルの 通気層空隙寸法の経時変化

考慮して呼び厚さに対して必ずプラス側とすることが規 定されているのみで, 特に製品厚さは定められていない。 通常は $120 \mathrm{~mm}$ 程度の開棝復元厚さとなるような復元力 を持たして製造・出荷されている。そのため, 内装材の 施工直後より，断熱材の復元力がシート状防風材を外側 に脹らませることとなり, シート B , C , Eモデルでは施 工直後瞬時に空隙が $1 \mathrm{~mm}$ 以下まで減少し中央部は殆ど 外装材裹面に接触している状態となる。またシート A, F モテルは内装材施工直後は $5 \mathrm{~mm}$ 程度の空隙が確保され ているが, 26 日経過後は上記モデルと同様の結果となっ た。比較的引張強度の高いシートDモデルでも，175 日 までは $4 \mathrm{~mm}$ 程度の空隙で推移した後, 僅かな減少が見 
られる。このことは，断熱材の復元力がかなり長期的に 持続していることの現れであろう。

高性能GW16K-100mm を充填したモデルの通気層空隙 寸法の経時変化を図 3 に示す。内装材施工前の空隙寸法 は一般品と殆ど差は無い。しかし，内装材施工直後も 4 $5 \mathrm{~mm}$ 程度減少するに留まり, 経時により微減する 傾向がみられるものの，301 日経過後も $4 \sim 8 \mathrm{~mm}$ 程度 の空隙が確保されている。GW16 K-100mm (一般品) と 比へて空隙が確保されている理由は，この断熱材も圧縮 相包されているが, 開相復元厚さを110 115 mm 程度と 低く抑えているためであると推測できる。

GW24K-100mm を充填したモデルの通気層空隙寸法の 経時変化も図 3 中に示す。ここではシートAのみを対象 としたが，開梱復元厚さが $105 \mathrm{~mm}$ 程度に設定して製造・ 出荷されているため，高性能 GW とほぼ同じ傾向となっ ている。

吹込み用断熱材を用いたモデルの通気層空隙寸法の経 時変化を図 4 に示す。ここではシート A，Bを対象とし
たが，断熱材種別に拘わらず，内装材施工前の空隙寸法 は $5 \mathrm{~mm}$ 程度になり, 内装材施工直後から 26 日経過まで の間に空隙が 1 2 $\mathrm{mm}$ 以下まで減少し，その後の変化 が余り見られない。他のモテルと比へて長期的変化が少 ない理由は，この方法に用いた断熱材は施工後短期間で 固形化するため，その後のシート材に及ぼす影響が殆ど 無いためである。また，総じてバット状断熱材の充填モ デルより空隙が少ない理由は, 施工時の断熱材の吹込み 圧力や充填密度が高いことによるものであろう。

\section{（2）通気層の空隙性状について}

内装材施工直後及び26日経過時のモテル上中下部の通 気層の空隙分布状況を図 5 ～7 に示す。なお，図は上中 下部毎に center 部は $\mathrm{Hc}, \mathrm{Mc}, \mathrm{Lc}$ 計測值，90 mm 部は $\mathrm{Hs}, \mathrm{Ms}$,Ls 計測値を用い，実際の形状に近似し得るよう曲 線化し作成したものである。

GW16K-100mm 充填モデルについては, 施工直後から モデル上中下部の center 部, $90 \mathrm{~mm}$ 部共, 外装材裹面に 接するまで空隙が減少しているモデル（シートC，E）

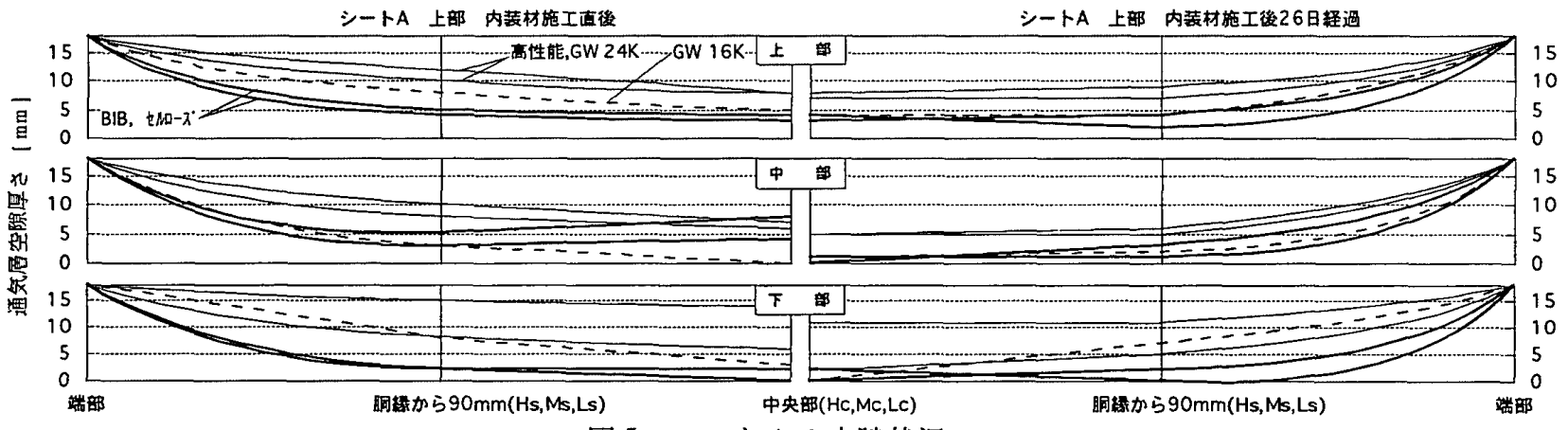

図 5 シートAの空隙状況

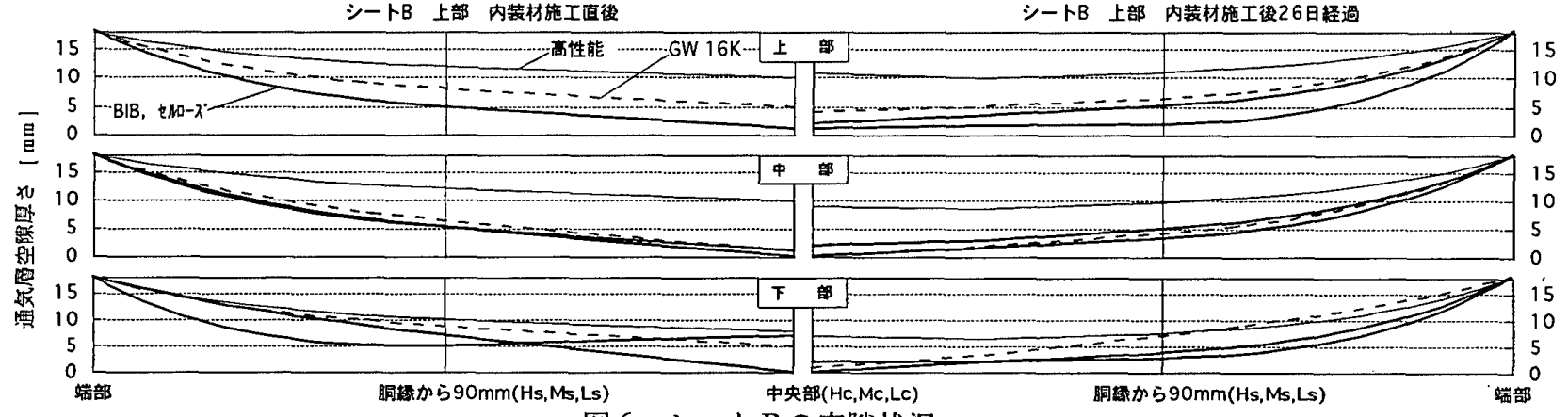

図 6 シートBの空隙状況

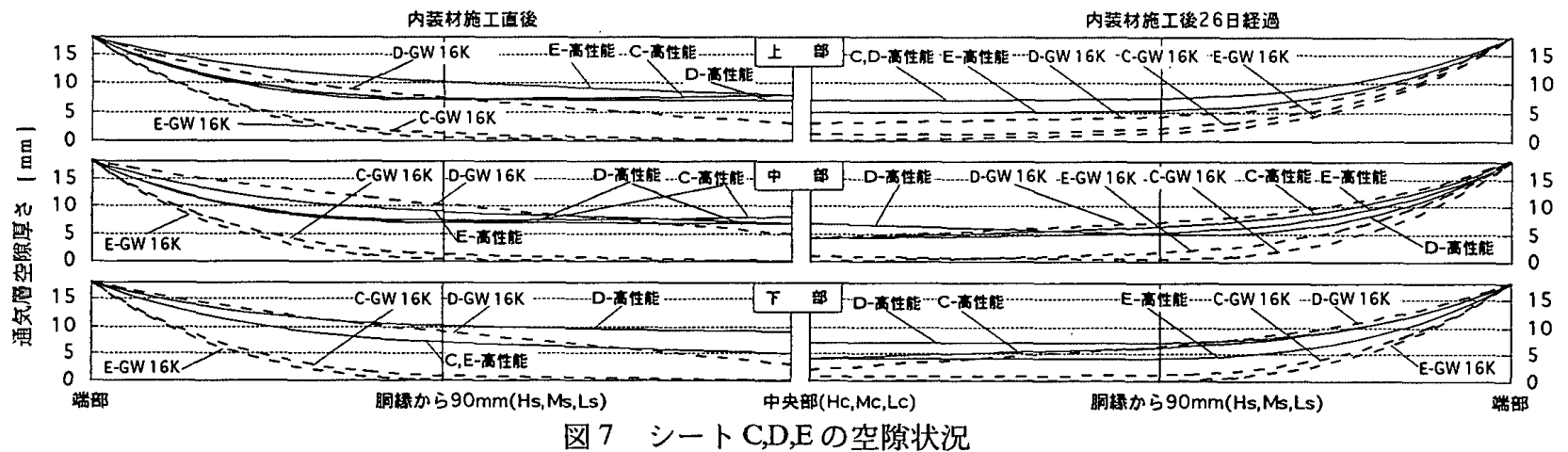


は，26日経過後，ほぼ完全に外装材裏面に接し，通気胴 縁材近傍の僅かな部分にしか空腺が残らない状況となっ ている。また，施工直後は全域で空隙が確保されていた モデル (シートA，B，C) でも，26日経過後，特に中. 下部の center 部・90 mm 部における空隙減少が顕著で, '下脹扎状態'となり，上部を除くと空隙は䏤縁材近傍に しかない状況となっている。この'下脹れ状態'となる理 由は，断熱材が自重で僅かに垂れ下がったことによるも のと考えられる。

高性能 GW1 $6 \mathrm{~K}-100 \mathrm{~mm}$ 充填モテルについては，施工直 後から26日経過にかけて，モデル中下部の各計測点で 僅かに空隙が減少しているものの，シ一ト材が外装材裏 面に接する部分は無く，全域に渡り通気層空隙が確保さ れ，'下脹れ状態'も見られない。また，GW16K-100mm モデルと比べて, center 部と $90 \mathrm{~mm}$ 部の空隙寸法の差異 が少ないのが特徴的であり，これは復元厚さの違いによ るものと考えられる。このことは, GW $24 \mathrm{~K}-100 \mathrm{~mm}$ 充填 モテルでも同様である。

吹込み断熱モデルについては，施工直後から各計測点 の空隙は僅かである。26日経過後は僅かな空陌減少に よって各点で外装材裹面に接する状態となり，GW16K$100 \mathrm{~mm}$ モデルより通気層空隙の閉鎖性が高いのが特徴的 である。

4. 通気層空陌の減少に伴う有効換気面稙と図形シミュ レーションによる検討

4.1 検討方法

3で述べたような通気層空隙の減少を示す一指標とし て，換気に有効な空隙量がどの程度減少するかを把握す るため，無風に近い安穏日にシロッコファンによる減圧 法にて風量と差圧を測定し，有効換気面積を求めた。な お，ここで求めた有効換気面積は通気層下端部（水切り 鉄板上部 $12 \mathrm{~mm}$ のスリット) 及び上端部（軒裏を介して 有孔ボード) 納まりの隙間性状も含むものである。测定 方法の概要・測定機器の詳細を図 8 に示す。測定は, シー 卜防風材を用いた典型的な空隙性状を有する 9 タイプの モデル壁と，比較のためボード状防風材（シージング ボード）を用いて通気層厚 $18 \mathrm{~mm}$ が確保されたモテル壁 の計 10 タイプを対象に行った。測定対象モテルを表 1 に 示す。

\section{2 検討結果と考察}

測定モデルの有効換気面積と $\mathrm{Mc}$ 部分の空隙寸法の相 関を図 9 ・表 2 に示す。参考までに横軸に，Mc・Ms 部分 の空隙寸法実測值を基に, 市販 CADソフトで求めたシー 卜延長長さ, 変化率, 通気層空隙面積も合わせて示す。

有効換気面積は, 通気層が全域で $18 \mathrm{~mm}$ 確保されたモ デ壁（防風層にシージングボードを使用）に比べ，モ デル中部 $\mathrm{Mc}$ の空隙寸法が $5 \mathrm{~mm}$ 程度までは空隙寸法

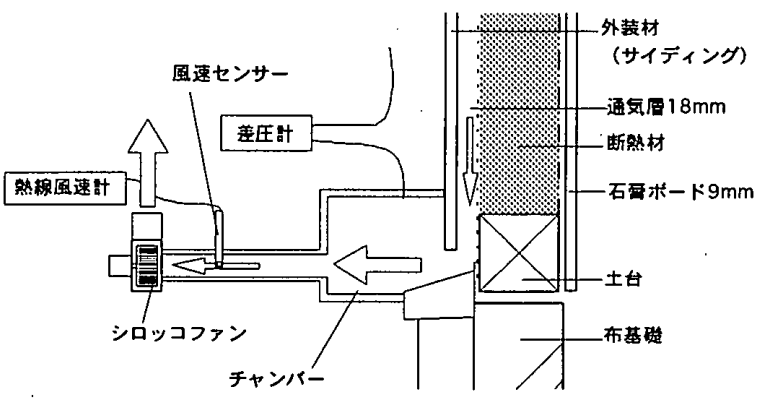

図 8 有効換気面積測定概要

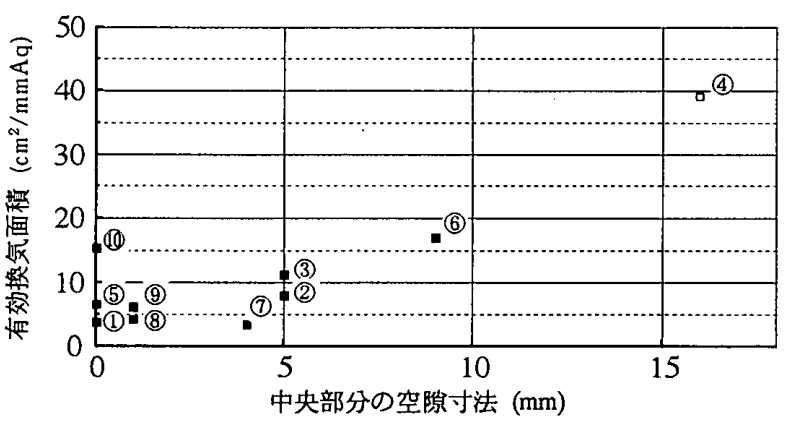

図9 空隙寸法 (中央部分) と有効換気面積

表 $2 \mathrm{Mc}$ 部空隙寸法・空隙面積・シート材長さの相関

\begin{tabular}{c|c|c|c|c}
\hline \multirow{2}{*}{$\begin{array}{c}\text { Mc部 } \\
\text { 空隙寸法 }\end{array}$} & \multicolumn{2}{|c|}{ 通気層空隙面橨 } & \multicolumn{2}{c}{ シート材曲線長さ } \\
\hline $18 \mathrm{~mm}$ & 69.8 & 100.0 & 388 & 100.0 \\
\hline $11 \mathrm{~mm}$ & 54.8 & 78.5 & 392 & 100.5 \\
\hline $8 \mathrm{~mm}$ & 44.6 & 64.0 & 396 & 101.8 \\
\hline $5 \mathrm{~mm}$ & 36.8 & 52.7 & 400 & 103.1 \\
\hline $0 \mathrm{~mm}$ & 20.2 & 29.0 & 408 & 104.6 \\
\hline
\end{tabular}

にほぼ比例して低下するが, 同望隙寸法が $4 \mathrm{~mm}$ 以下に なると $10 \%$ 程度にまで減少する。

図形シミュレーションより, 例えば空隙寸法が $5 \mathrm{~mm}$ 程度の場合, シート長さは, 施工時 (胴縁材間内法寸法 : $388 \mathrm{~mm}$ ) に比べて $12 \mathrm{~mm}$ 程度 (変化率で $3 \%$ 程度) 増加 したことになる。実験壁の解体調査では，ジート材固定 部及びガンタッカー周辺部で引裂き等が生じシート長さ が変化したという形跡がないことから, シート材の変形 は断熱材の復元圧による材料自体の伸びが主因と考えら れる。

\section{5. 総 括}

5.1 実験結果のまとめ

寒冷地で一般的な $103 \mathrm{~mm}$ 厚の軸間に断熱材を全充填 する断熱壁体において，市場流通しているシート状防風 材を用いた場合の通気層空隙に関しては，本論文で行っ た実験より下記のことが明らかとなった。

（1）シート状防風材を用いた場合の通気層空隙は，使用 する断熱材の開相復元厚さや吹込み圧等による影響を著 しく受ける。

（2）特に，GW16K-100mm を充填した場合は，長期に 渡る断熱材復元王によって施工直後からシート材が外側 
にはらみ，通気胴縁材近傍を除く殆どの部分で外装材裏 面に接触する危険性が高く，それに伴う通気量低下も著 しい。

（3）高性能 GW16 K-100 mm・GW24K-100mm を充填し た場合は，緩みなく適切にシート材の施工を行えば，通 気層空隙は確保できるものの, 空隙・通気量は本来の半 分以下まで減少する危険性が高い。

（4）吹込み用断熱材による場合は，断熱材種による差異 は少ないが，固形化までの初期的段階で胴縁材近傍部を 除く殆どの部分で通気層が閉鎖するなど，GW $16 \mathrm{~K}-$ $100 \mathrm{~mm}$ と同様なことがいえる。

（5）これらの空隙・通気量の城少は，シート材自体の微 少な寸法変化で容易に発生する。これは，本実験上の主 因と推測される材料自体の僅かな伸び以外に, 強風施工 時等におけるシート材の僅かな緩み・撓みによっても， 通気層が閉鎖される危険性が高いことを示唆している。

これらの結果は, 冬期における壁体内の結露防止, 通 年に渡る木材の乾燥化, 乾式外装材の温度収縮等による シール切れやティテールの不備等が主因で生じた漏雨水 の排水等, 通気層が持つ役割を阻害する恐れがあること を示している。

\section{2 工法的提案}

シート状防風材を前提とした場合の，通気層空隙を確 保するための措置としては次のように整理できる。

ア. 縅維系断熱材 (ボード品を除く) を充填する場合

(1) 断熱材の復元厚さを壁厚程度に設定する。

(2) シート状防風材の変形防止のため伸度を抑える。

(3) 通気層内にスペーサを設置する。

(4) 開棝復元厚さより大きな通気胴縁材を使用する。

このうち，(1)は運搬費の増加に伴う材料のコストアッ プや，この対策を行った場合でも断熱材を押し込みすぎ

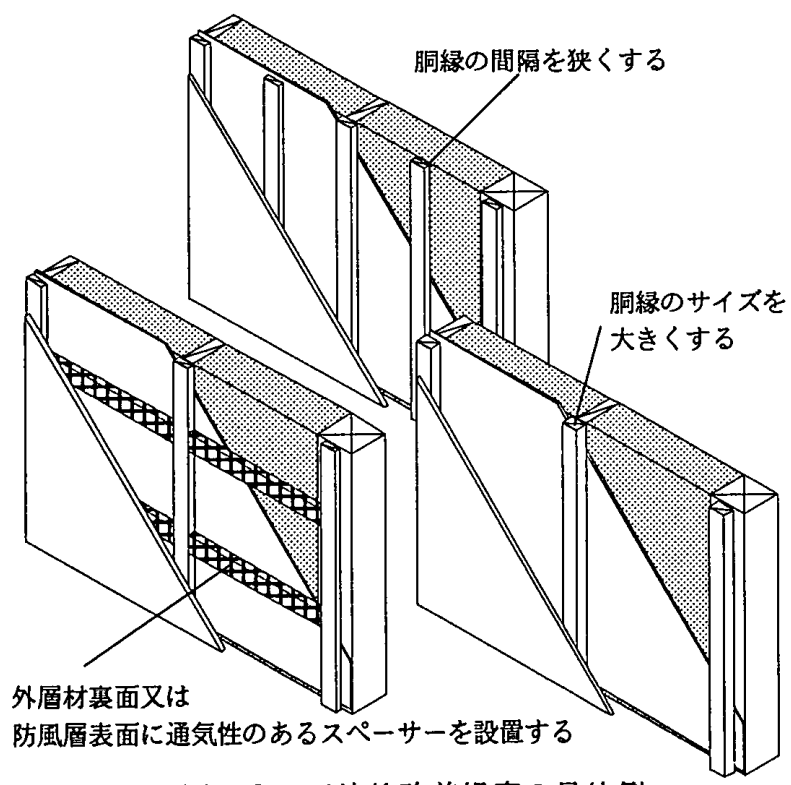

図 10 工法的改善提案の具体例
た場合は通気層空隙の確保に対する信頼性に問題がある。 また，(2)は市場流通品に無く新たな材料開発が必要であ ること，施工時の緩みや強風施工時の撓み等の施工要因 がからんだ場合には有効な解決策とはなり得ないことに 問題が残る。以上のことから，通気層堡隙を確保するに は，(1)(2)のような材質的改良より，(3)(4)に示したような 工法的対処による方法が, 現実的かつ信頼性が高いとい える。これらの工法的提案の具体例を図 10 に示す。

イ、吹込み断熱方法による場合

この方法は吹込み王力が高いことから, シート状防風 材の使用は避け，面剛性の高いボード状防風材の使用を 前提とすべきであろう。

本論文では外壁断熱に着目して検討を行った。現在寒 冷地では，外壁の他に屋根断熱でも通気層を設け，厚さ $200 \mathrm{~mm}$ 以上のバット状断熱材を充填するか吹込み断熱方 法を用いるケースが多くなってきている。前者による場 合は, 設計段階から十分な断熱・通気スペースを確保し た屋根構造とすることで通気層空隙の減少については解 決できよう。しかし, 最近は断熱施工の容易性から後者 による場合が多く、シート状防風材を使用した場合には 外壁と同様な問題が生じる危険性がある。従って, 吹込 みによる屋根断熱を行う場合にもボード状材料による通 気層確保が重要と思われる。

謝 辞

本研究の実施にあたり, 硝子絨維協会, 北海道職業能 力開発短期大学校教官佐々木 隆氏に御協力・御指導頂い た。記して感謝の意を表します。

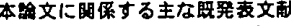

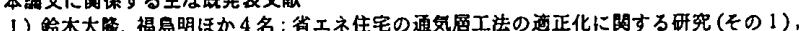

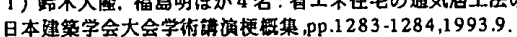

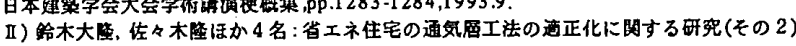

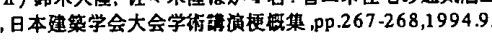

考文献

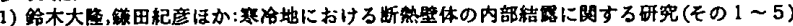

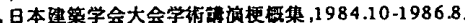

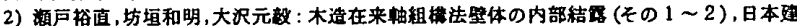

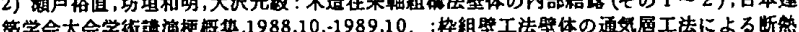

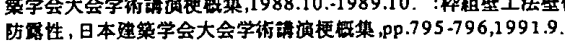

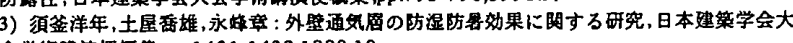
会学街暆演梗既果,pp.1431-1432,1990.10.

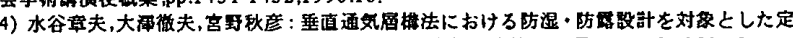

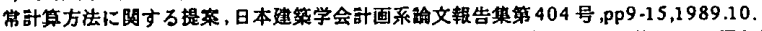

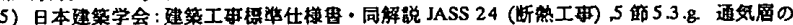
施工 pp12.1995.2.

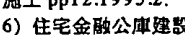

国版, 北海道版) , 1994.

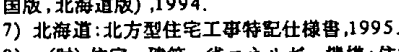

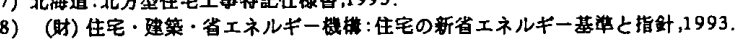

1) 北海道の外照軸組木材は呼称寸法て $45 \mathrm{~mm} \times 105 \mathrm{~mm}, 105 \mathrm{~mm} \times 105 \mathrm{~mm}$ 等の3 寸 5 分材

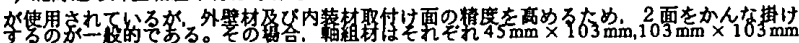
等となる。実状に合わせるため本実驗ては $103 \mathrm{~mm}$ を壁厚に設定した。

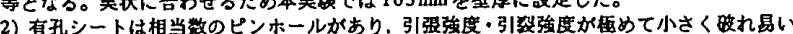

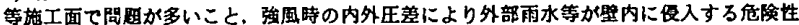

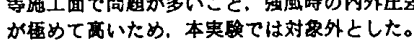

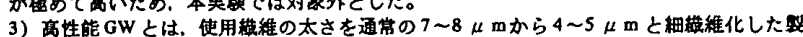

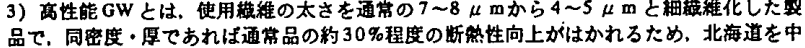
心とした寒合地或て近年急速に音及している断㷛材てある。
}

（1995年 6 月 7 日原稿受理，1995年 9 月 27 日採用决定） 